\title{
TINGKAT KEPUASAN PENGGUNA FASILITAS PENYEBERANGAN ORANG (STUDI KASUS JPO MUKA KUNING KOTA BATAM)
}

\author{
Harry Kurniawan ${ }^{1}$ dan Nadia Khaira $\mathrm{Ardi}^{2}$ \\ ${ }^{1,2}$ Program Studi Teknik Sipil, Universitas Riau Kepulauan Batam, \\ Jl. Batu Aji Baru Batam \\ Email: nadia.khairaardi01@gmail.com
}

\begin{abstract}
Abstrak
Jembatan Penyeberangan Orang (JPO) di Kawasan Industri Muka Kuning Batam yang dibangun tahun 2011, terlihat belum dimanfaatkan secara optimal. Penelitian ini dilakukan untuk mengetahui indikator apa saja yang penting dan diharapkan penyeberang jalan ada di JPO. Beberapa tahapan survey dilakukan seperti survey kondisi fisik JPO, geometrik jalan, serta wawancara penyeberang jalan. Data dianalisis dengan pendekatan kuantitatif mengacu pada Perencanaan Teknis Fasilitas Pejalan Kaki, Pd 03 - 2017 - B dan pendekatan Importance Performance Analysis (IPA) dan Customer Satisfaction Index (CSI). Hasil penelitian menunjukkan bahwa fisik jembatan yang dibuat sudah sesuai dengan standar disain jembatan penyeberangan, kecuali ukuran optradeltinggi tanjakan dan kemiringan tangga yang lebih besar dari yang disyaratkan. Hasil pengelompokan 8 indikator pelayanan berdasarkan interpretasi CSI menunjukkan bahwa kondisi fisik JPO (atap, lantai, pegangan tangga, lampu penerang) merupakan hal penting yang diharapkan oleh para pengguna JPO yang dalam pelaksanaannya belum memuaskan para pengguna JPO. Harapannya, pembangunan infrastruktur harus dibarengi dengan kegiatan pemeliharaan insfratruktur yang ada agar sesuai dengan umur perencanaannya.
\end{abstract}

Kata kunci: Jembatan Penyeberangan Orang (JPO), Pendekatan IPA, CSI, Pejalan Kaki

\section{PENDAHULUAN}

Banyak keluarga merasa lebih baik jika masyarakat mereka memiliki sebuah sistem transportasi yang efisien dan seimbang dengan layanan angkutan umum, bersepeda dan jalan kaki berkualitas baik, daripada jika masyarakat mereka tergantung pada mobil, yang mengharuskan setiap keluarga menanggung ongkos kepemilikan kendaraan, mendanai pembangunan jalan dan fasilitas parkir, menghadapi kemacetan lalu lintas dan menanggung biaya tinggi kecelakaan lalu lintas.

Praktek perencanaan konvensional memungkinkan lalu lintas mobil mendominasi ruang jalan kota. Walaupun dalam teorinya motoris dan non-motoris memiliki hak yang sama untuk menggunakan jalan umum, lalu lintas kendaraan bermotor mendorong keluar pengguna lainnya karena bahaya dan ukurannya yang lebih besar serta kecepatannya yang lebih tinggi. Mobil menggunakan 10 sampai 50 kali ruang per penumpang dibanding moda lain dan ia membahayakan keselamatan para pejalan kaki dan pengguna sepeda. Manajemen yang lebih efisien memberikan prioritas untuk moda yang membutuhkan lebih sedikit ruang per penumpang-kilometer, dan terutama pada perjalanan bernilai tinggi seperti angkutan umum penumpang dan angkutan barang.

JPO atau Jembatan Penyeberangan Orang adalah fasilitas fisik penyeberangan tidak sebidang bagi pejalan kaki yang dibangun untuk meminimalisir konflik lalu lintas dengan penyeberangan jalan. Pembangunan jembatan penyeberangan disarankan di suatu ruas jalan apabila fasilitas penyeberangan dengan menggunakan zebra cross dan pelican cross sudah mengganggu lalu lintas yang ada, tingginya frekuensi kecelakaan yang melibatkan pejalan kaki, dan besarnya arus lalu lintas volume pejalan kaki di ruas jalan tersebut. 
Sejumlah JPO dibangun di beberapa ruas jalan yang mempunyai volume lalulintas padat dengan jumlah penyeberang jalan yang cukup banyak. Salah satunya adalah JPO yang terletak di Kawasan Industri Muka Kuning Kota Batam. Sayangnya, JPO yang sudah dibangun sejak tahun 2011 ini sepertinya tidak dimanfaatkan secara optimal oleh pengguna jalan. Padahal volume lalu lintas di kawasan ini sangat padat. Untuk menghindari orang tetap melintas di jalan raya, dibuatlah pagar pembatas di median jalan. Namun ternyata hal ini tidak menghalangi sejumlah pejalan kaki untuk tetap mengambil resiko berkonflik dengan arus lalulintas. Dibeberapa titik, terlihat pagar pembatas yang dibongkar, sehingga banyak pejalan kaki yang melintas di bekas bongkaran pagar tersebut. Tidak hanya pejalan kaki. Sejumlah sepeda motor pun, terlihat menerobos melewati pagar tersebut.

Penelitian ini dilakukan untuk mengetahui indikator apa saja yang penting dan diharapkan penyeberang jalan ada di JPO melalui wawancara dengan para pejalan kaki yang memanfaatkan fasilitas ini. Pengolahan data mengacu pada Pedoman Perencanaan Jalur Pejalan Kaki pada Jalan Umum No. 032/T/BM/1999, pendekatan Importance Performance Analysis (IPA) dan Customer Satisfaction Index (CSI)

\section{LANDASAN TEORI}

\section{Pendekatan IPA}

Dalam penelitian Idris, Zilhardi (2009) disebutkan bahwa Importance Performance Analysis (IPA) merupakan alat bantu dalam menganalisis atau membandingkan sejauh mana kinerja/pelayanan yang dapat dirasakan oleh pengguna jasa dibandingkan terhadap tingkat kepuasan yang diinginkan. Untuk mengukur tingkat kepentingan dan tingkat kepuasan/kinerja terhadap jawaban responden, digunakan skala 5 tingkat (skala Likert). Dari hasil penilaian tingkat kepentingan dan hasil penilaian kinerja, maka akan diperoleh suatu perhitungan mengenai tingkat kesesuaian antara tingkat kepentingan dan tingkat pelaksanaannya oleh penyedia jasa. Tingkat kesesuaian merupakan hasil perbandingan antara skor kinerja pelaksanaan dengan skor kepentingan, sehingga tingkat kesesuaian inilah yang akan menentukan skala prioritas yang akan dipakai dalam penanganan faktorfaktor yang mempengaruhi kepuasan pengguna jasa transportasi di perkotaan. Untuk keperluan ini ada dua buah variabel yang akan menentukan tingkat kinerja penyedia jasa pelayanan yaitu dengan menggunakan simbol $\mathrm{X}$ dan ingkat kepentingan pengguna jasa pelayanan dengan simbol Y sebagaimana dijelaskan dengan model matematika sebagai berikut :

$$
\begin{aligned}
T_{k} & =\frac{X}{Y} \times 100 \% \\
\bar{X} & =\frac{\sum X}{N} \\
\bar{Y} & =\frac{\sum Y}{N}
\end{aligned}
$$

Dengan $\mathrm{Tk}=$ Tingkat kesesuaian responden, $\mathrm{X}=$ Importance an pelaksanaan kinerja pelayanan jasa, $\mathrm{Y}=$ Skor penilaian kepentingan pengguna jasa, $\bar{X}=$ Skor ratarata tingkat kepuasan/kinerja, $\bar{Y}=$ Skor ratarata tingkat kepentingan dan $\mathrm{N}=$ Jumlah responden. Selanjutnya tingkat unsur-unsur atau pemetaan dari atribut akan dijabarkan atau dikelompokkan dalam salah satu dari empat kuadran yang disebut dengan diagram kartesius yang dibatasi oleh sumbu $\mathrm{X}$ dan sumbu Y, seperti terlihat dari diagram di bawah ini.

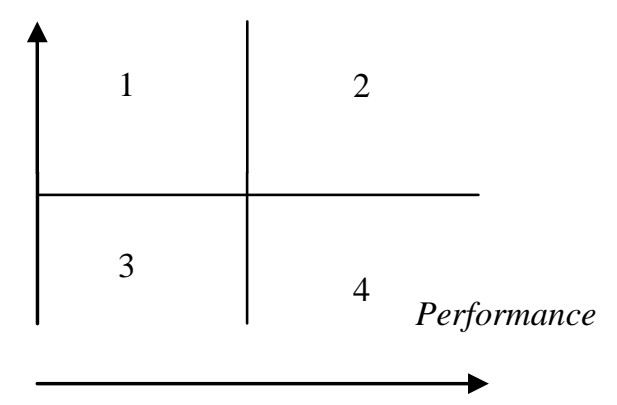


Gambar 1. Importance-Performance Grid

Diagram Kartesius

Pengertian dari empat kuadran diagram kartesius tersebut di atas adalah sebagai berikut :

$\checkmark$ Kuadran 1 : Importance tinggi sedangkan performance rendah, artinya pada kondisi ini, dari sisi kepentingan pengguna jasa, dimana faktor-faktor yang mempengaruhi pelayanan pada tingkat tinggi, sedangkan dari sisi kepuasan, pengguna merasakan tingkat yang rendah (tidak puas) sehingga menuntut adanya perbaikan atribut oleh penyedia jasa.

$\checkmark$ Kuadran 2 : Importance tinggi sedangkan performance juga tinggi, artinya pada kondisi ini, dari sisi pengguna jasa, faktor-faktor yang mempengaruhi pelayanan pada tingkat yang tinggi, sedangkan kepuasan pengguna jasa juga pada tingkat yang tinggi (sudah puas). Dalam hal ini penyedia jasa diharapkan dapat

Tabel 1. Rekomendasi Nilai CSI

\begin{tabular}{cc}
\hline Angka Indeks & Interpretasi Nilai CSI \\
\hline $\mathrm{X}<64 \%$ & Very Poor \\
\hline $64 \%<\mathrm{X}<71 \%$ & Poor \\
\hline $71 \%<\mathrm{X}<77 \%$ & Cause For Concern \\
\hline $77 \%<\mathrm{X}<80 \%$ & Border Line \\
\hline $80 \%<\mathrm{X}<84 \%$ & Good \\
\hline $84 \%<\mathrm{X}<87 \%$ & Very Good \\
\hline$>87$ & Excellent \\
\hline
\end{tabular}

\section{DATA DAN PEMBAHASAN}

Ruas jalan Muka Kuning - Tembesi (Jl. Letjen Suprapto) merupakan ruas jalan nasional berdasarkan Keputusan Menteri PU No. 290/KPTS/M/2015. Tipe jalannya 2 mempertahankan

pelayananan/kinerjanya

$\checkmark$ Kuadran 3 : Importance rendah sedangkan performance juga rendah, artinya pada kondisi ini, faktor-faktor yang berhubungan dengan pelayanan tidak penting bagi pengguna, kinerja penyedia jasa biasa-biasa saja dan juga pengguna tidak merasa puas dengan pelayanan yang diberikan.

$\checkmark$ Kuadran 4 : Importance rendah sedangkan performance tinggi, artinya pada kondisi ini faktor-faktor yang mempengaruhi pelayanan tidak penting bagi pengguna, tapi pengguna sudah merasa puas.

\section{Indeks Kepuasan Pelanggan (Customer} Satisfaction Index = CSI).

Dalam menentukan atau mengukur tingkat kepuasan pelanggan dapat ditentukan dengan indikator nilai CSI yang mempertimbangkan tingkat harapan pengguna jasa terhadap faktor-faktor yang akan ditentukan. Berdasarkan rekomendasi yang diusulkan oleh Balitbang-Dephub (Siswoyo, 2007) maka nilai kepuasan pelanggan adalah seperti di bawah ini :

jalur terbagi. Satu jalur lebarnya 7 meter dengan lebar bahu kiri dan kanan masingmasing 2 meter dan lebar median 4 meter. Survey wawancara dilakukan selama 2 (dua) hari, yaitu pada hari Minggu tanggal 1 April 2018 mewakili hari libur dan Senin 2 April 2018 mewakili hari kerja.

\section{Data fisik jembatan}

Data fisik JPO Muka Kuning dapat dilihat pada Tabel 5. Terlihat bahwa fisik jembatan yang dibuat sudah sesuai dengan standar disain jembatan penyeberangan, kecuali untuk ukuran optrade/tinggi tanjakan > 21,5 $\mathrm{cm}$ dan kemiringan tangga $>20^{\circ}$ (lebih besar dari yang disyaratkan). 
Tabel 2. Data Fisik Jembatan

\begin{tabular}{|c|c|c|c|}
\hline No & Uraian & $\begin{array}{c}\text { Jembatan } \\
\text { Penyeberangan }\end{array}$ & $\begin{array}{c}\text { Standar Desain } \\
\text { Jembatan } \\
\text { Penyeberangan }\end{array}$ \\
\hline 1 & Panjang (m) & 46,3 & \\
\hline 2 & Lebar (m) & 3,1 & \\
\hline 3 & Tinggi (m) & 3 & \\
\hline 4 & Jenis Konstruksi & Baja & \\
\hline \multicolumn{4}{|c|}{ A. Bagian Utara JPO (Tembesi - Muka Kuning) } \\
\hline & 1. Lebar Tangga $(\mathrm{cm})$ & 202 & Minimum 200 \\
\hline & $\begin{array}{l}\text { 2. Aantrede/Lebar Jalan } \\
(\mathrm{cm})\end{array}$ & 30 & $21,5-30,5$ \\
\hline & $\begin{array}{l}\text { 3. Optrade/Tinggi Tanjakan } \\
(\mathrm{cm})\end{array}$ & 20 & $15-21,5$ \\
\hline \multicolumn{4}{|c|}{ 4. Borders/Tempat Istirahat } \\
\hline & a. Panjang $(\mathrm{cm})$ & 210 & Minimum 150 \\
\hline & b. Lebar $(\mathrm{cm})$ & 240 & Minimum 200 \\
\hline \multicolumn{4}{|c|}{ Bagian Selatan JPO (Muka Kuning - Tembesi) } \\
\hline & 1. Lebar Tangga $(\mathrm{cm})$ & 222 & Minimum 200 \\
\hline & $\begin{array}{l}\text { 2. Aantrede/Lebar Jalan } \\
(\mathrm{cm})\end{array}$ & 30 & $21,5-30,5$ \\
\hline & $\begin{array}{l}\text { 3. Optrade/Tinggi Tanjakan } \\
(\mathrm{cm})\end{array}$ & 24 & $15-21,5$ \\
\hline \multicolumn{4}{|c|}{ 4. Borders/Tempat Istirahat } \\
\hline & a. Panjang $(\mathrm{cm})$ & 253 & Minimum 150 \\
\hline & b. Lebar $(\mathrm{cm})$ & 222 & Minimim 200 \\
\hline 5 & Kemiringan Tangga $\left({ }^{\circ}\right)$ & $45^{0}$ & Maksimum $20^{0}$ \\
\hline
\end{tabular}

Sumber : Hasil Survey, 2018

\section{Data Karakteristik Penyeberang Jalan}

Karakteristik penyeberang jalan, dikumpulkan melalui sebaran kuisioner sebanyak 137 kuisioner, 18 diantaranya tidak kembali sehingga total jumlah kuisioner yang diolah sebanyak 119 buah. Komposisi responden dapat dijelaskan sebagai berikut :

Tabel 3. Komposisi Responden Berdasarkan Jenis Kelamin

\begin{tabular}{|l|r|r|}
\hline \multicolumn{1}{|c|}{ Jenis Kelamin } & Jumlah & Persentase \\
\hline a. Laki-laki & 37 & 31,09 \\
\hline b. Perempuan & 82 & 68,91 \\
\hline Jumlah Total & 119 & 100 \\
\hline
\end{tabular}

Dari hasil olahan kuisioner, didapatkan karakteristik penyeberang jalan sebagai berikut :

\section{Usia dan Tingkat Pendidikan}

Rata-rata penyeberang jalan mempunyai latar belakang pendidikan minimal SLTA $(64,71 \%)$ dan usia rata-rata penyeberang jalan didominasi oleh usia antara 21-30 tahun sebanyak 51,26\%. Sebaran usia dan latar belakang pendidikan penyeberang jalan dapat dilihat pada gambar 2 dan gambar 3. 


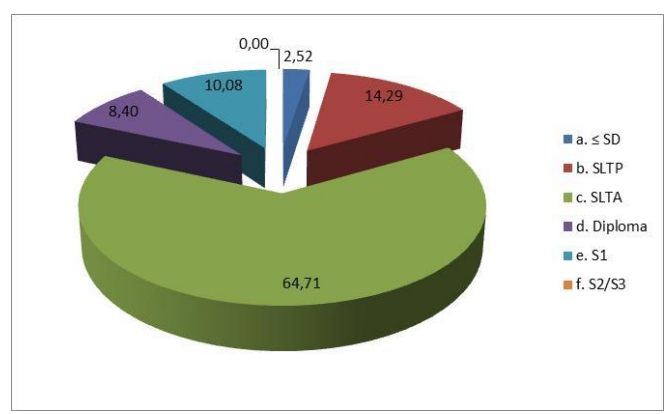

Gambar 2. Persentase tingkat pendidikan penyeberang jalan

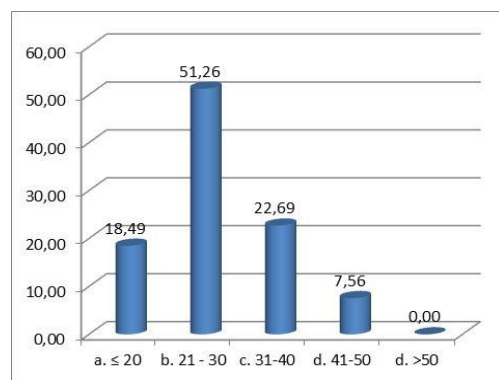

Gambar 3. Persentase usia penyeberang jalan

\section{Tingkat Kepuasan Pengguna JPO}

Hasil analisis interpretasi nilai Customer Satification Index (CSI) terhadap 8 indikator/atribut JPO yang dipertanyakan, menunjukkan bahwa pelayanan yang diberikan masih sangat buruk. Hal ini terlihat dari nilai rasio antara tingkat kinerja/kepuasan dengan tingkat kepentingan/harapan pengguna.

Tabel 4. Tingkat Kepuasan Responden Terhadap JPO

\begin{tabular}{|c|c|c|c|c|c|c|c|}
\hline NO. & INDIKATOR & $\begin{array}{l}\text { SANGAT } \\
\text { PUAS }\end{array}$ & PUAS & $\begin{array}{l}\text { CUKUP } \\
\text { PUAS }\end{array}$ & $\begin{array}{l}\text { KURANG } \\
\text { PUAS }\end{array}$ & $\begin{array}{l}\text { TIDAK } \\
\text { PUAS }\end{array}$ & $\begin{array}{l}\text { JUMLAH } \\
\text { TOTAL }\end{array}$ \\
\hline 1 & Kebersihan JPO & 1 & 14 & 17 & 64 & 23 & 119 \\
\hline 2 & Keamanan Pengguna JPO & 2 & 33 & 38 & 34 & 12 & 119 \\
\hline 3 & $\begin{array}{l}\text { Lebar area yang luas untuk } \\
\text { berjalan di JPO }\end{array}$ & 0 & 42 & 40 & 27 & 10 & 119 \\
\hline 4 & $\begin{array}{l}\text { Jarak ke/dari pemberhentian } \\
\text { sarana angkutan umum }\end{array}$ & 0 & 42 & 42 & 30 & 5 & 119 \\
\hline 5 & $\begin{array}{l}\text { Waktu tempuh ke/dari } \\
\text { pemberhentian sarana angkutan } \\
\text { umum }\end{array}$ & 0 & 42 & 47 & 24 & 6 & 119 \\
\hline 6 & Lebar dan tinggi anak tangga & 1 & 39 & 48 & 24 & 7 & 119 \\
\hline 7 & $\begin{array}{l}\text { Kondisi fisik JPO (atap, lantai, } \\
\text { pegangan tangga, lampu } \\
\text { penerang) }\end{array}$ & 1 & 4 & 21 & 56 & 37 & 119 \\
\hline 8 & $\begin{array}{l}\text { Keselamatan penyeberang } \\
\text { jalan }\end{array}$ & 3 & 35 & 45 & 27 & 9 & 119 \\
\hline & Nilai Rata-Rata & 8 & 251 & 298 & 286 & 109 & 952 \\
\hline
\end{tabular}

Tabel 5. Tingkat Harapan Responden Terhadap JPO

\begin{tabular}{llllllll}
\hline NO. & \multicolumn{1}{c}{ INDIKATOR } & $\begin{array}{l}\text { SANGAT } \\
\text { PUAS }\end{array}$ & PUAS & $\begin{array}{l}\text { CUKUP } \\
\text { PUAS }\end{array}$ & $\begin{array}{l}\text { KURANG } \\
\text { PUAS }\end{array}$ & $\begin{array}{l}\text { TIDAK } \\
\text { PUAS }\end{array}$ & $\begin{array}{l}\text { JUMLAH } \\
\text { TOTAL }\end{array}$ \\
\hline 1 & Kebersihan JPO & 49 & 50 & 20 & 0 & 0 & 119 \\
\hline 2 & Keamanan Pengguna JPO & 58 & 51 & 10 & 0 & 0 & 119 \\
\hline
\end{tabular}




\begin{tabular}{|c|c|c|c|c|c|c|c|}
\hline 3 & $\begin{array}{l}\text { Lebar area yang luas untuk } \\
\text { berjalan di JPO }\end{array}$ & 38 & 56 & 22 & 3 & 0 & 119 \\
\hline \multirow[t]{2}{*}{4} & $\begin{array}{l}\text { Jarak ke/dari pemberhentian } \\
\text { sarana angkutan umum }\end{array}$ & 39 & 56 & 19 & 5 & 0 & 119 \\
\hline & $\begin{array}{l}\text { Waktu tempuh ke/dari } \\
\text { pemberhentian sarana angkutan } \\
\text { umum }\end{array}$ & 38 & 50 & 26 & 5 & 0 & 119 \\
\hline \multirow[t]{2}{*}{6} & Lebar dan tinggi anak tangga & 39 & 40 & 34 & 6 & 0 & 119 \\
\hline & $\begin{array}{l}\text { Kondisi fisik JPO (atap, lantai, } \\
\text { pegangan tangga, lampu } \\
\text { penerang) }\end{array}$ & 94 & 24 & 1 & 0 & 0 & 119 \\
\hline \multirow[t]{2}{*}{8} & $\begin{array}{l}\text { Keselamatan penyeberang } \\
\text { jalan }\end{array}$ & 101 & 17 & 1 & 0 & 0 & 119 \\
\hline & Nilai Rata-Rata & 456 & 344 & 133 & 19 & 0 & 952 \\
\hline NO. & INDIKATOR & $\begin{array}{c}\text { BOBOT } \\
\text { KINERJA }\end{array}$ & \multicolumn{2}{|c|}{$\begin{array}{c}\text { BOBOT } \\
\text { HARAPAN }\end{array}$} & $\begin{array}{c}\text { TINGKAT } \\
\text { KESESUAIAN }\end{array}$ & $X$ & Y \\
\hline 1 & Kebersihan JPO & 263 & \multicolumn{2}{|c|}{505} & $52,08 \%$ & 2,21 & 4,24 \\
\hline 2 & Keamanan Pengguna JPO & 336 & \multicolumn{2}{|c|}{524} & $64,12 \%$ & 2,82 & 4,40 \\
\hline 3 & $\begin{array}{l}\text { Lebar area yang luas untuk } \\
\text { berjalan di JPO }\end{array}$ & 352 & \multicolumn{2}{|c|}{486} & $72,43 \%$ & 2,96 & 4,08 \\
\hline 4 & $\begin{array}{l}\text { Jarak ke/dari pemberhentian } \\
\text { sarana angkutan umum }\end{array}$ & 359 & \multicolumn{2}{|c|}{486} & $73,87 \%$ & 3,02 & 4,08 \\
\hline 5 & $\begin{array}{l}\text { Waktu tempuh ke/dari } \\
\text { pemberhentian sarana angkutan } \\
\text { umum }\end{array}$ & 363 & \multicolumn{2}{|c|}{478} & $75,94 \%$ & 3,05 & 4,02 \\
\hline 6 & Lebar dan tinggi anak tangga & 360 & \multicolumn{2}{|c|}{469} & $76,76 \%$ & 3,03 & 3,94 \\
\hline 7 & $\begin{array}{l}\text { Kondisi fisik JPO (atap, lantai, } \\
\text { pegangan tangga, lampu } \\
\text { penerang) }\end{array}$ & 233 & \multicolumn{2}{|c|}{569} & $40,95 \%$ & 1,96 & 4,78 \\
\hline 8 & $\begin{array}{l}\text { Keselamatan penyeberang } \\
\text { jalan }\end{array}$ & 353 & \multirow{2}{*}{\multicolumn{2}{|c|}{576}} & $61,28 \%$ & 2,97 & 4,84 \\
\hline & Nilai Rata-Rata & & & & & 2,75 & 4,30 \\
\hline
\end{tabular}

Tabel 10. Tingkat Kepuasan Berdasarkan Interpretasi CSI

\begin{tabular}{llccl}
\hline NO. & \multicolumn{1}{c}{ INDIKATOR } & $\begin{array}{c}\text { TINGKAT } \\
\text { KESESUAIAN }\end{array}$ & $\begin{array}{c}\text { YANG } \\
\text { BELUM } \\
\text { SESUAI }\end{array}$ & $\begin{array}{c}\text { INTERPRETASI } \\
\text { CSI }\end{array}$ \\
\hline 1 & Kebersihan JPO & $52,08 \%$ & $47,92 \%$ & Very Poor \\
\hline 2 & Keamanan Pengguna JPO & $64,12 \%$ & $35,88 \%$ & Poor \\
\hline $\begin{array}{l}\text { Lebar area yang luas untuk berjalan } \\
\text { di JPO }\end{array}$ & $72,43 \%$ & $27,57 \%$ & $\begin{array}{l}\text { Cause For } \\
\text { Concern }\end{array}$ \\
\hline Jarak ke/dari pemberhentian sarana & & & Cause For \\
4 & angkutan umum & $73,87 \%$ & $26,13 \%$ & Concern \\
\hline 5 & Waktu tempuh ke/dari & $75,94 \%$ & $24,06 \%$ & Cause For \\
\hline
\end{tabular}




\begin{tabular}{|c|c|c|c|c|}
\hline & $\begin{array}{l}\text { pemberhentian sarana angkutan } \\
\text { umum }\end{array}$ & & & Concern \\
\hline 6 & Lebar dan tinggi anak tangga & $76,76 \%$ & $23,24 \%$ & $\begin{array}{l}\text { Cause For } \\
\text { Concern }\end{array}$ \\
\hline 7 & $\begin{array}{l}\text { Kondisi fisik JPO (atap, lantai, } \\
\text { pegangan tangga, lampu penerang) }\end{array}$ & $40,95 \%$ & $59,05 \%$ & Very Poor \\
\hline 8 & Keselamatan penyeberang jalan & $61,28 \%$ & $38,72 \%$ & Very Poor \\
\hline
\end{tabular}

Interpretasi penyebaran 8 indikator ke dalam diagram kartesius dapat dilihat pada gambar berikut ini :

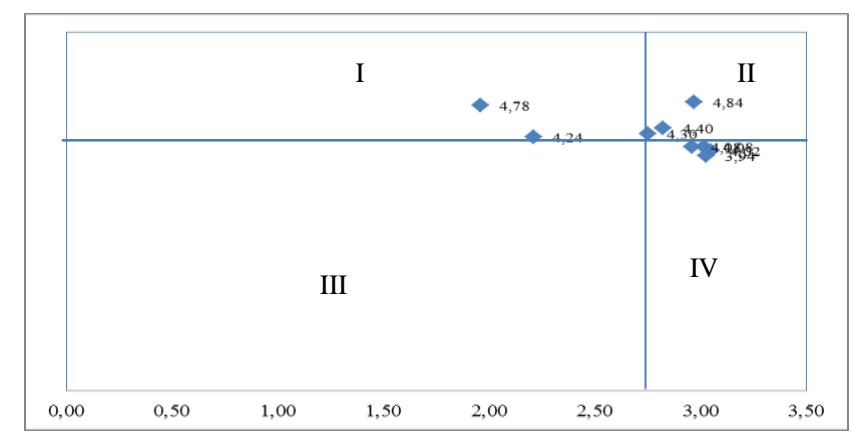

Gambar 4. Diagram Kartesius Tingkat Kepuasan Pengguna JPO Muka Kuning Sumber : Hasil Survey, 2018

Interpretasi penyebaran 8 indikator/atribut ke dalam empat bagian diagram kartesius dapat dijelaskan sebagai berikut :

1. Kuadran I

Indikator 7 (Kondisi fisik JPO : atap, lantai, pegangan tangga, lampu penerang) merupakan hal penting yang diharapkan oleh para pengguna JPO yang dalam pelaksanaannya belum memuaskan para pengguna JPO. Kondisi fisik JPO dapat dilihat pada Gambar 5.
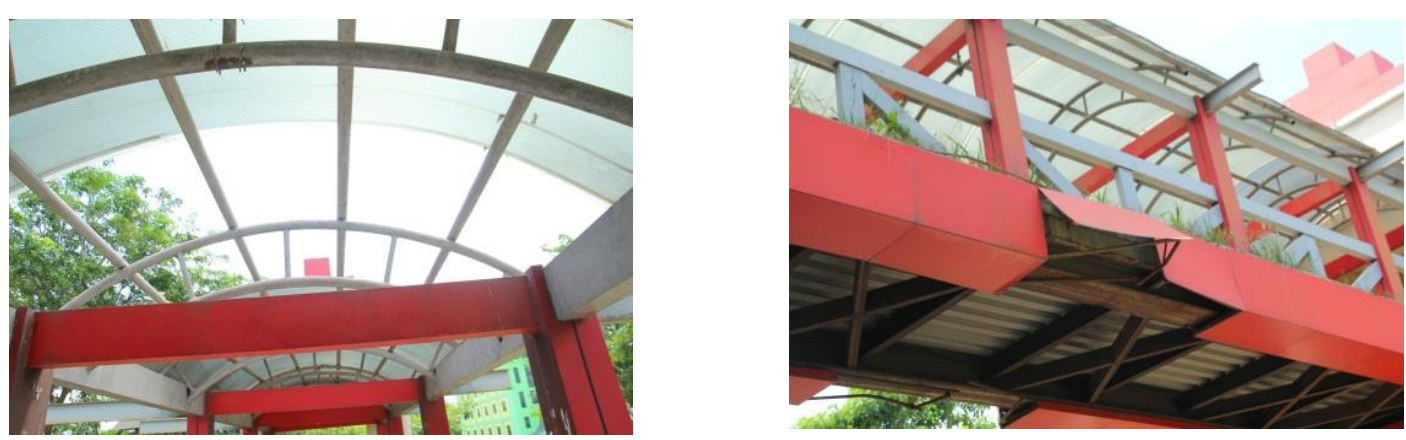

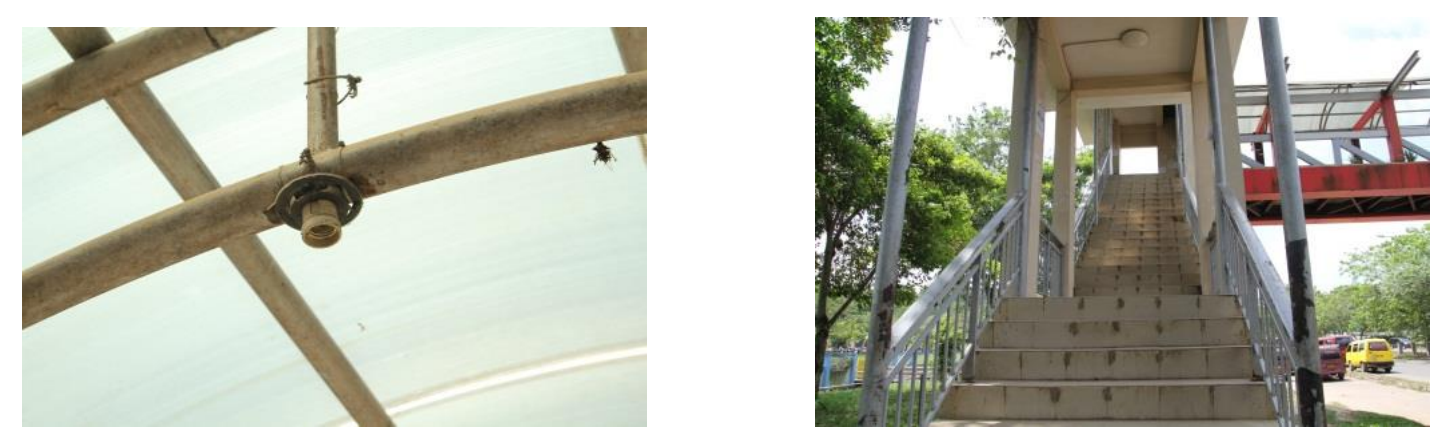

Gambar 5. Kondisi Fisik JPO

\section{Kuadran II}

Indikator 2 (keamanan pengguna JPO) dan 8 (keselamatan penyeberang jalan), juga merupakan hal yang dirasa penting oleh pengguna JPO yang dalam keberadaannya dinilai responden cukup baik, dan perlu dipertahankan.
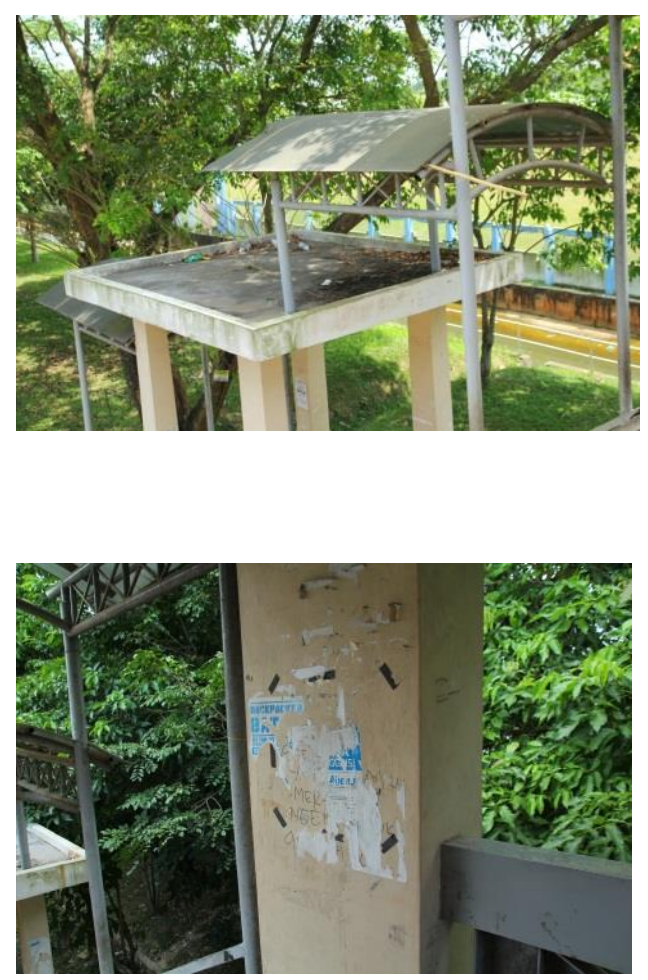

3. Kuadran III

Indikator 1 (kebersihan JPO), tidak menjadi point penting oleh pengguna JPO, yang dalam pelaksanaannya pun dirasa masih belum memuaskan. Kondisi kebersihan JPO dapat dilihat pada gambar 6 berikut ini.
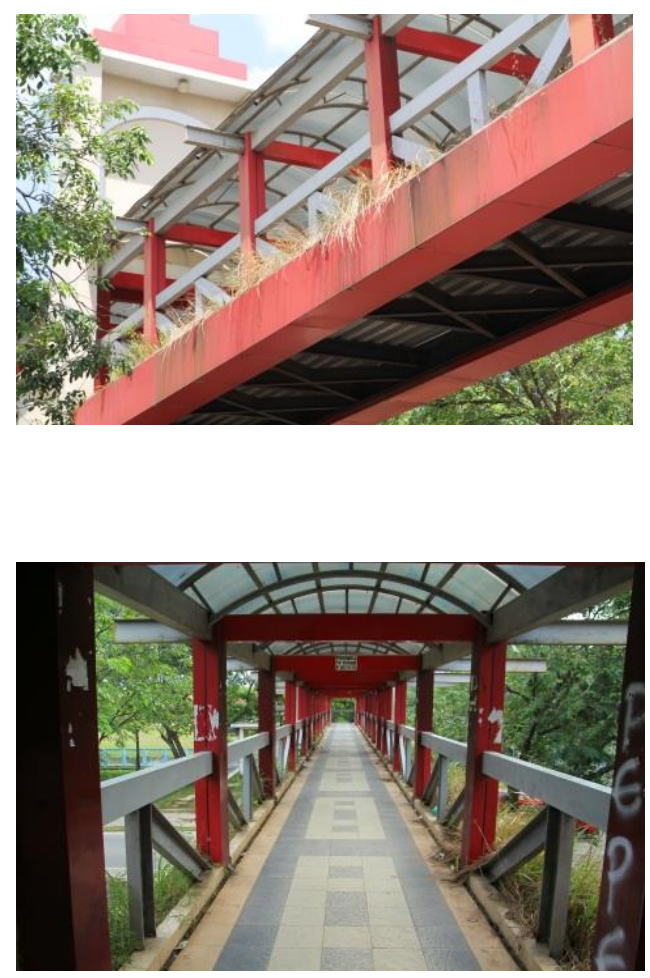
Gambar 6. Kondisi Kebersihan JPO

\section{Kuadran IV}

Indikator 3 (lebar area yang luas untuk berjalan di JPO), indikator 4 (jarak ke/dari pemberhentian sarana angkutan umum), indikator 5 (waktu tempuh ke/dari pemberhentian sarana angkutan umum) dan indikator 6 (Lebar dan tinggi anak tangga), tidak menjadi item penting bagi pengguna JPO, namun mendapat penilaian yang cukup memuaskan.
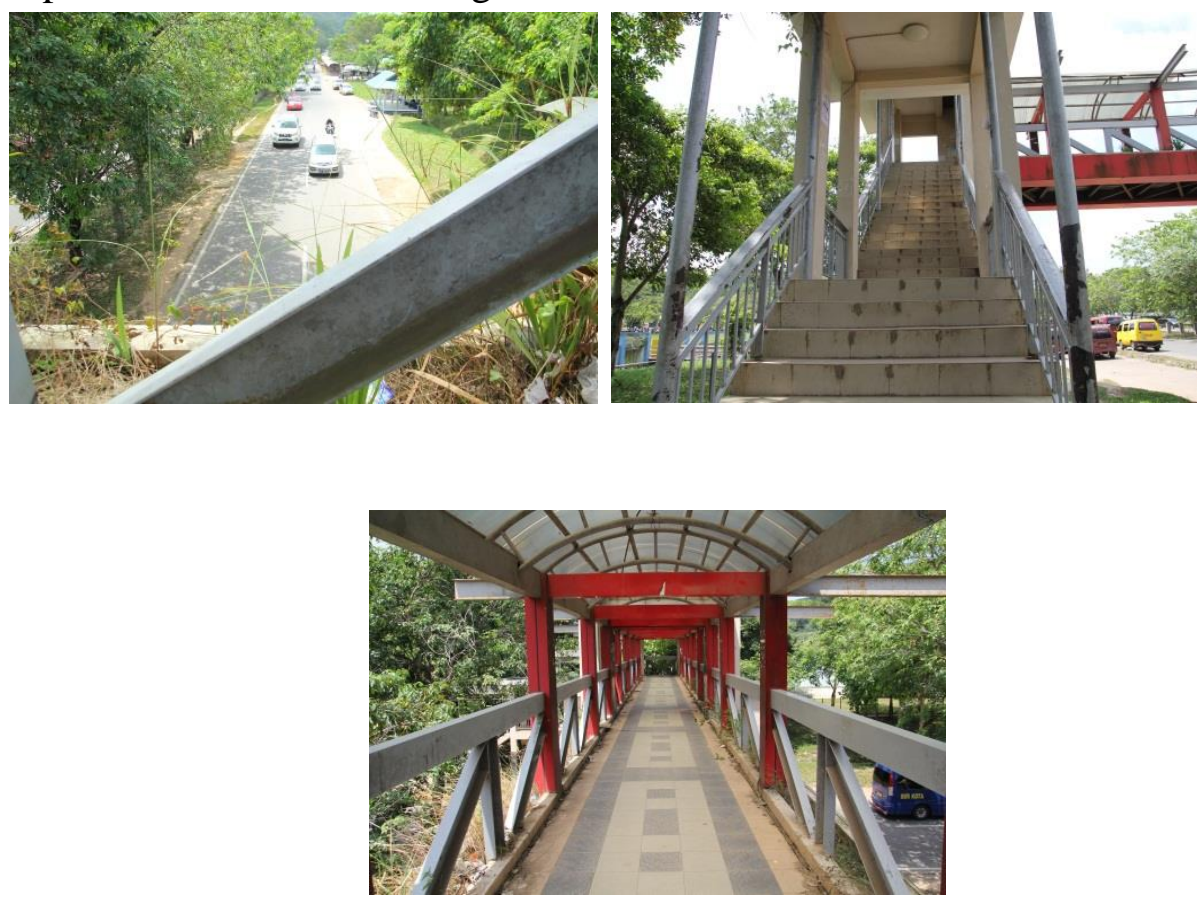

Gambar 7. Lebar area JPO dan Jarak dari Halte

\section{KESIMPULAN}

Berdasarkan hasil pengolahan data di JPO Muka Kuning dapat ditarik kesimpulan sebagai berikut:

1. Hasil penelitian menunjukkan bahwa fisik jembatan yang dibuat sudah sesuai dengan standar disain jembatan penyeberangan, kecuali ukuran optrade/tinggi tanjakan $>21,5 \mathrm{~cm}$ dan kemiringan tangga $>20^{\circ}$ (yang lebih besar dari yang disyaratkan)

2. Hasil pengelompokan 8 indikator pelayanan berdasarkan interpretasi CSI menunjukkan bahwa persentase yang belum sesuai dengan yang diharapkan pengguna rata-rata di bawah 50\%, sehingga secara umum, bisa disimpulkan bahwa pengguna JPO cukup puas dengan kondisi JPO yang ada saat ini.

3. Interpretasi CSI juga menunjukkan bahwa Indikator kebersihan JPO, kondisi fisik JPO (atap, lantai, pegangan tangga, lampu penerang) dan keselamatan penyeberang jalan harus lebih ditingkatkan lagi, agar penyeberang jalan merasa aman dan nyaman menggunakan JPO

4. Diagram kartesius tingkat kepuasan pengguna JPO menunjukkan bahwa Indikator Kondisi fisik JPO : atap, lantai, pegangan tangga, lampu penerang) merupakan hal penting yang 
diharapkan oleh para pengguna JPO yang dalam pelaksanaannya belum memuaskan para pengguna JPO.

5. Pembangunan infrastruktur publik harus disertai dengan pemeliharaan rutin infrastruktur tersebut. Karena jika tidak kerusakan bangunan akan lebih cepat terjadi yang berdampak terhadap keamanan dan keselamatan pengguna jalan.

\section{DAFTAR PUSTAKA}

Ardi, Nadia (2011). Kondisi Fasilitas Fisik Pejalan Kaki di Indonesia. Jurnal Dimensi, Universitas Riau Kepulauan Batam.

Idris, Z. (2007). Jembatan Penyeberangan Di Depan Kampus UMS Sebagai Fasilitas Pejalan Kaki. Dinamika TEKNIK SIPIL, Volume 7, Nomor 1, Januari 2007, 87 - 93

Idris, Z. (2009). Kajian Tingkat Kepuasan Pengguna Angkutan Umum di DIY. Dinamika TEKNIK SIPIL, Volume 9, Nomor 2, Juli 2009, 189 - 196

Departemen Pekerjaan Umum. (1995). Tata Cara Perencanaan Jembatan
Penyeberangan Pejalan Kaki di Perkotaan No. 027/T/Bt/1995. Dirjen Bina Marga, Jakarta

Departemen Pekerjaan Umum. (1999). Pedoman Perencanaan Jalur Pejalan Kaki pada Jalan Umum No. 032/T/BM/1999. Dirjen Bina Marga, Jakarta

Departemen Pekerjaan Umum. (2017). Perencanaan Teknis Fasilitas Pejalan Kaki, Pd 03 - 2017 - B. Dirjen Bina Marga, Jakarta

Kurniati, T \& Gunawan, H. (2007). Pemanfaatan Fasilitas Jembatan Penyeberangan Oleh Pejalan Kaki di Kota Padang. Jurnal Rekayasa Sipil, Jurusan Teknik Sipil, Fakultas Teknik, Universitas Andalas Vol. 3 No. 1 Februari 2007, ISSN : 18582133

Mashuri, Widodo, S. (2012). Tingkat Pemanfaatan dan Faktor-faktor yang mempengaruhi Pemakaian Jembatan Penyeberangan Orang di depan Mall Tatura Kota Palu, Mektek, Tah un XIV, No. 1, Januari 2012 